\title{
Six cases of purpuric eruptions induced by epidermal growth factor receptor inhibitors
}

\author{
Tomoko Hiraiwa, Yuka Hanami, Toshiyuki Yamamoto
}

Department of Dermatology, Fukushima Medical University, Hikarigaoka 1, Fukushima 960-1295, Japan

Corresponding author: Dr. Tomoko Hiraiwa, E-mail: toishi@fmu.ac.jp

Sir,

Erlotinib $\left(\right.$ Tarceva $\left.{ }^{\circledR}\right)$ and gefitinib $\left(\right.$ Iressa $\left.{ }^{\circledR}\right)$ are novel oral tyrosine kinase inhibitors targeting epidermal growth factor receptor (EGF-R). A number of skin reactions have been induced, however, purpuric eruption is rare. We report six cases of purpuric lesions some of which exhibited clinically mimicking HenochSchönlein purpura that occurred after treatment with EGF-R inhibitors for lung cancers. Two were men and four were women, and the mean age was 67.8 years (range: 60 to 80 year old). Clinical presentations are shown in Fig. 1, and the summary of cases is shown in Table 1. On physical examination, all cases had many small purpuric lesions with a diameter of 1-2 $\mathrm{mm}$ on the lower extremities, and trunk was also involved in one case. All of the cases were palpable purpura. Five cases had pustules in the center of purpuric lesions, and xerosis was observed in all cases. Erlotinib was thought to be the causative agent in three cases, two of them were switched from gefitinib to erlotinib, whereas other three cases were due to gefitinib. The duration ranged between 2 weeks and 6 months (mean: 2.9 months) after starting EGF-R inhibitors. Histopathological examination was performed in four cases, which revealed mild infiltrate of lymphocytes around the capillaries and extravasation of red blood cells in the upper dermis (Fig. 2), but there were no finding of leukocytoclastic vasculitis. Direct immunofluorescence was performed in one case, and there was no deposition of immunoglobulins. Skin eruptions were spontaneously improved by only interruption of the causative drugs, almost within 1 week. Platelet counts and coagulation profiles were within normal ranges in all cases. Four cases showed a favorable response to EGF-R inhibitors. By contrast,

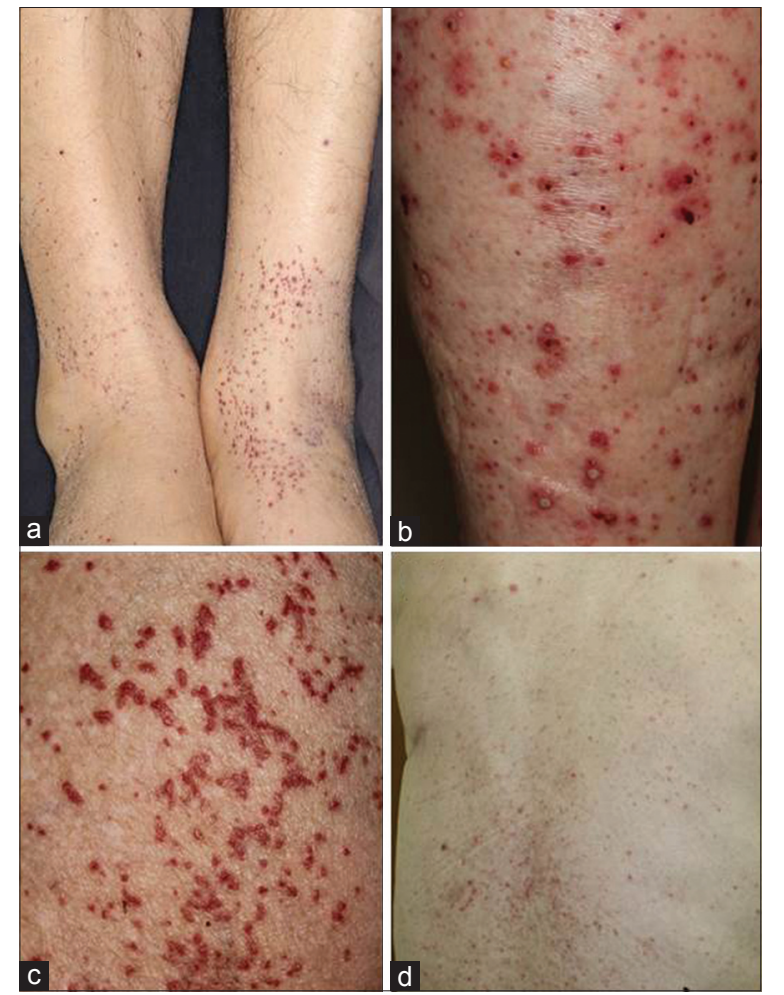

Figure 1: A significant number of palpable purpuric lesions on the lower leg (a-c). Pustular lesions are also seen (b). Purpuric lesions spread on the back (d).

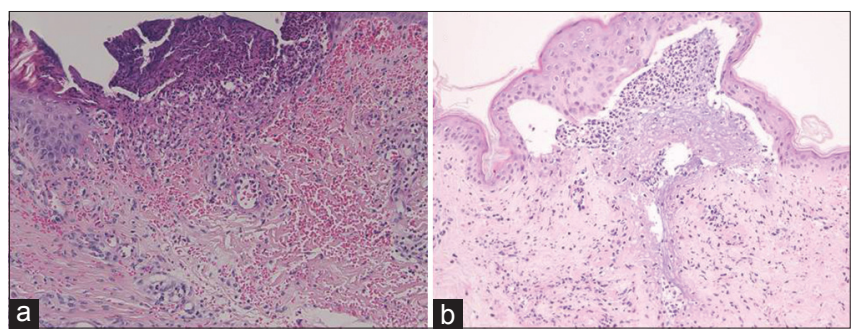

Figure 2: Histopathological findings from papulopustular lesions show neutrophilic infiltration and a neutrophilic abscess in the epidermis $(a, b)$. Extravasation of erythrocytes and perivascular lymphocytes are seen in the upper dermis (H-E stain, magnification x200).

\footnotetext{
How to cite this article: Hiraiwa T, Hanami Y, Yamamoto T. Six cases of purpuric eruptions induced by epidermal growth factor receptor inhibitors. Our Dermatol Online. 2018;9(1):89-90.

Submission: 15.02.2017; Acceptance: 30.05.2017

DOI: 10.7241 /ourd.20181.27
} 
Table 1: Characteristics of patients presenting with purpuric lesions during EGF-R inhibitor treatmen

\begin{tabular}{|c|c|c|c|c|c|c|c|c|c|c|c|}
\hline \multirow[t]{2}{*}{ Case } & \multirow[t]{2}{*}{ Age } & \multirow[t]{2}{*}{ Sex } & \multirow[t]{2}{*}{$\begin{array}{l}\text { Primary } \\
\text { illness }\end{array}$} & \multirow[t]{2}{*}{$\begin{array}{c}\text { EGF-R inhibitor (Dose, } \\
\text { Duration) }\end{array}$} & \multirow[t]{2}{*}{$\begin{array}{l}\text { Prior } \\
\text { use }\end{array}$} & \multirow[t]{2}{*}{ Site } & \multirow[t]{2}{*}{ Pustule } & \multirow[t]{2}{*}{ Xerosis } & \multirow[t]{2}{*}{ Other } & \multicolumn{2}{|c|}{$\begin{array}{l}\text { Histopathological } \\
\text { findings }\end{array}$} \\
\hline & & & & & & & & & & Vasculitis & IF \\
\hline 1 & 68 & $\mathrm{~F}$ & $\begin{array}{l}\text { Lung } \\
\text { cancer }\end{array}$ & Erlotinib (150 mg/day, 2 weeks) & Gefitinib & $\begin{array}{l}\text { Lower } \\
\text { legs }\end{array}$ & + & + & paronychia & - & - \\
\hline 2 & 71 & $\mathrm{~F}$ & $\begin{array}{l}\text { Lung } \\
\text { cancer }\end{array}$ & Erlotinib (150 mg/day, 2 months) & Gefitinib & Legs & + & + & - & - & n.d. \\
\hline 3 & 60 & M & $\begin{array}{l}\text { Lung } \\
\text { cancer }\end{array}$ & Gefitinib (250 mg/day, 3 months) & - & $\begin{array}{l}\text { legs } \\
\text { abdomen } \\
\text { chest }\end{array}$ & + & + & - & n.d. & n.d. \\
\hline 4 & 64 & M & $\begin{array}{l}\text { Lung } \\
\text { cancer }\end{array}$ & Gefitinib (250 mg/day, 3 weeks) & - & Ankles & - & + & Paronychia & - & n.d. \\
\hline 5 & 64 & $\mathrm{~F}$ & $\begin{array}{l}\text { Lung } \\
\text { cancer }\end{array}$ & Gefitinib (250 mg/day, 5 months) & - & Legs & + & + & $\begin{array}{l}\text { Paronychia, } \\
\text { acneform } \\
\text { eruption of the } \\
\text { head and face }\end{array}$ & - & n.d. \\
\hline 6 & 80 & $\mathrm{~F}$ & $\begin{array}{l}\text { Lung } \\
\text { cancer }\end{array}$ & Erlotinib (100 mg/day, 6 months) & - & Legs & + & + & $\begin{array}{l}\text { Acneform } \\
\text { eruption of the } \\
\text { face }\end{array}$ & n.d. & n.d. \\
\hline
\end{tabular}

in 2 cases, EGF-R inhibitors started after multiple metastases occurred, and both of them died.

To date, several cases of purpuric eruptions after treatment with gefitinib have been reported, among which leukocytoclastic vasculitis was observed in 4 cases, whereas association with erlotinib have been reported in only a few cases [1]. Our cases did not show vasculitis, and three out of the four cases did not present with folliculitis even by serial cut sections. EGF-R is expressed by endothelial cells in the skin, and thus EGF-R inhibitor altered the vessel morphology, vascular dilation, and vascular permeability $[2,3]$. Therefore, inhibition of EGF-R on the endothelial cells of cutaneous vessels may contribute to the induction of minor vascular impairment, ectatic vessels, and extravasation of erythrocytes, leading to purpuric eruptions. Other possibilities such as occlusive vasculopathy of the subcutaneous vascular system, and increased platelet aggregation and thromboxane levels have been suggested [4]. Additionally, neutrophils may also be attracted to the epidermis via chemoattractants, forming pustules. EGF-R inhibitors-induced purpura occurs along with xerosis and pustules most frequently on the lower limbs, but rarely arises on the trunk at the early phase from initiation of therapies with EGF-R inhibitors. Among 6 cases presented here, favorable effects of EGF-R inhibitors were confirmed in 4 cases. Whether the development of purpuric eruptions are related to good response to EGF-R inhibitors or not should be determined in the future, accumulating more number of cases.

\section{REFERENCES}

1. Yamamoto T. Erlotinib-induced adverse skin reactions. Open Allergy J. 2013;6:22-9.

2. Van Doorn R, Kirtschig G, Scheffer E, Stoof TJ, Giaccone G. Follicular and epidermal alterations in patients treated with ZD1839 (Iressa), an inhibitor of the epidermal growth factor receptor. $\mathrm{Br}$ J Dermatol. 2002;147:598-601.

3. Cerniglia GJ, Pore N, Tsai JH, Schultz S, Mick R, Choe R, et al. Epidermal growth factor receptor inhibition modulates the microenvironment by vascular normalization to improve chemotherapy and radiotherapy efficacy. PLoS One2009;4:e6539.

4. Kurokawa S, Yamaguchi K. Kinoshita Y, Muramatsu M, Komiyama Y, Nomura S. Gefitinib affects functions of platelet and blood vessels via changes in prostanoids balance. Clin Appl Throm Hemost. 2005;11:429-34.

Copyright by Tomoko Hiraiwa, et al. This is an open access article distributed under the terms of the Creative Commons Attribution License, which permits unrestricted use, distribution, and reproduction in any medium, provided the original author and source are credited.

Source of Support: Nil, Conflict of Interest: None declared. 